\title{
Histological Observation of the Endometrium in Repeat Breeder Cows
}

\author{
Shintaro OHTANI* and Kiyoshi OKUDA ${ }^{1) * *}$ \\ Biei Veterinary Clinical Center, Kamikawa-chuo Agricultural Mutual Aid Association, Biei-cho, Hokkaido 071-02 and ${ }^{1)}$ Department of \\ Animal Science and Technology, Faculty of Agriculture, Okayama University, Tsushima, Okayama 700, Japan
}

(Received 23 August 1994/Accepted 19 December 1994)

ABSTRACT. The endometrium plays an important role during attachment and implantation of embryos. Using histological techniques,
we evaluated the morphological changes of the endometrium in repeat breeder cows. Endometrial biopsy specimens were obtained from
5 Holstein repeat breeder cows, 5 normally cyclic Holstein cows and 5 normally cyclic Holstein heifers on Days 1 and 8 after estrus. On
Day 1 , in the repeat breeder cows, the glandular secretions and supranuclear vacuolation were observed, but glandular mitoses were not
observed, whereas these secretory characteristics were not observed in the normal cows. However, the appearance of stromal mitoses,
stromal edema and pseudodecidual reaction was observed as in the normal cyclic cows. On Day 8 , in the repeat breeder cows, the
characteristics on the glandular indices were not different from those on Day 1 , and were similar to those of the normal cows on Day 8 .
But, the characteristics on the stromal indices, the stromal mitoses and pseudodecidual reaction, were not observed, although these
characteristics were observed in the normally cyclic cows. The presence of advanced morphology in the gland on Day 1 and the stroma
on Day 8 indicates that these two events are controlled independently. These endometrial asynchrony might result in cows repeat
breeding.-KEY woRDs: bovine, endometrium, estrous cycle, repeat breeder.

It is well established that ovarian steroids influence the development and function of the mammalian endometrium; estrogen is reported to stimulate proliferation of both luminal and glandular epithelium, and to stimulate secretion of uterine protein, and progesterone is reported to induce proliferative changes in the stroma and to increase glandular secretory activity [23]. These ovarian hormones act cooperatively to prepare and maintain the endometrium for implantation.

The ovarian hormones which control the uterine environment have also been shown to regulate the development of preimplantation embryos $[16,18,24]$. However, uterine mechanisms for regulating embryo development do not fully control the attachment and implantation, and the importance of synchrony between the embryo and uterus was recognized [8]. Some scientists reported an imbalance between glandular and stromal elements in the endometrium of women who were infertile, but had normal menstrual cycles and serum progesterone patterns $[3,10,24]$. To our knowledge, there have been no reports on endometrial function and development during implantation in repeat breeder cows.

Understanding the role of the endometrium in controlling implantation in the cow may assist in the development of treatments to improve the reproductive prolificacy of this species. The aim of the present study was to examine the histologic changes in the endometrium of repeat breeder cows during periimplantation: Days 1 and 8 .

* CuRRent ADdress: Division of Animal Science, Osaka Prefectural Agricultural and Forestry Research Center, 442 Shakudo, Habikino, Osaka 583, Japan.

** To whom reprint request should be addressed.

\section{MATERIALS AND METHODS}

Five repeat breeder Holstein cows (Table 1), 5 normally cyclic Holstein cows (6-8 years old: average 7.3, 3-6 parturitions: average 3.6) and 5 normally cyclic Holstein heifers (13-19 months old: average 15.4) from 3 commercial farms were used. All animals stayed on the farms throughout this study. The heifers were not inseminated before this experiment. After this experiment these heifers and cows except for repeat breeder cows became pregnant after artificial insemination and calved normally, or were confirmed conception. The repeat breeders were defined according to Hafez [9] as cows that return to service repeatedly after being bred to a fertile male, that exhibit normal signs of estrus every 18 to 24 days, and that require more than three services to become pregnant. Estrus was confirmed by daily observation of standing estrus and by palpation per rectum. All animals had elastic protuberant corpus luteum on Day 8. One person performed most of the inseminations on each farm, and semen from the same bull was used. Conception rates at the three farms were $57.9 \%, 60.8 \%$, and $82.8 \%$. All animals were fed orchardgrass hay, alfalfa hay, corn silage, beet pulp, soybean meal, barley grain, wheat millfeeds, minerals and vitamins formulated to NRC requirements [13]. The study was conducted throughout the year except July and August.

Uterine biopsies were taken on Days 1 and 8 of the estrous cycle from each cow and heifer (Day $0=$ day of estrus). On day 1 specimens were taken from the middle of the uterine horn ipsilateral to the vesicular folliclebearing ovary, and on Day 8 specimens were taken from the middle of both horns; thus each animal had three biopsies collected. The specimens taken from left and right horns were compared to examine whether the 
Table 1. Repeat breeder Holstein cows used

\begin{tabular}{cccc}
\hline Age (Years) & No. of calvings & Days after calvings & $\begin{array}{c}\text { No. of services } \\
\text { (received) after last } \\
\text { calving }\end{array}$ \\
\hline 6 & 4 & 216 & 3 \\
7 & 4 & 188 & 3 \\
7 & 6 & 205 & 3 \\
7 & 5 & 202 & 4 \\
7 & 6 & 254 & 4 \\
\hline
\end{tabular}

All cows had normal interestrous intervals and normal findings on visual vaginoscopic examination and palpation per rectum of the reproductive tract.

difference was observed between the results obtained from the uterine horns ipsilateral to the ovary with the corpus luteum and those obtained from contralateral horns. Biopsy specimens $(2.5 \times 1.5 \times 1.5 \mathrm{~mm})$ were obtained with a biopsy forceps (FB-21K, Olympus, Tokyo, Japan) and immersed immediately in Bouin's fixative. After $24 \mathrm{hr}$ the specimens were embedded in paraffin, sectioned $6 \mu \mathrm{m}$-thick, and stained with hematoxylin and eosin.

The morphological changes in all cows and heifers were evaluated with the methods published previously [15]. First the scores of normal cyclic cows, which made with the methods, were compared with those of normal cyclic heifers to evaluate whether these methods were useful to estimate the endometrium of multiparous cows, because the methods were based on the observation on heifers. Then the scores of repeat breeder cows were compared with those of normal cyclic cows.

Blood samples were taken from the coccygeal vein of all cows on Days 0,1 and 8. The samples were placed on ice immediately after blood collection, and plasma was separated within 5 min by centrifugation (3,000 r.p.m., 10 $\mathrm{min}$ ), and stored at $-20^{\circ} \mathrm{C}$ until analysis. Plasma progesterone concentrations were determined by radioimmunoassay as described by Makino [11]. The limit of sensitivity within this study was $0.3 \mathrm{ng} / \mathrm{m} l$ and the interand intra-assay coefficients of variation were $14.0 \%$ and $8.0 \%$, respectively.

Prior to obtaining the endometrial biopsy, uterine horns were flushed with sterile physiologic saline solution (20 $\mathrm{m} l$ ) on Days 1 and 8. Uterine flushings were placed on ice and transported to the laboratory for analysis. Identification of bacterial species was done by standard bacteriologic analysis at the Daiichi Medical Testing Laboratory (Asahikawa, Japan). The cows that had specific bacterial infections such as C. pyogenes, Coliforms and Streptococci were removed from the study.

The endometrial data were analyzed by Mann-Whitney $\mathrm{U}$ test and plasma progesterone concentrations were analyzed using Student's $t$-test and paired $t$-test.

RESULTS

There were no significant differences in all scores in the endometrium between normal cows and normal heifers, hence, these two groups were considered the same. But significant morphological differences were observed between repeat breeder cows and normal cows (Table 2).

On Day 1, in the normally cyclic cows, glandular mitoses appeared, while supranuclear vacuolation was not observed. However, the specimens from repeat breeder cows revealed a secretory endometrium: glandular secretions and supranuclear vacuolation were prominent, and glandular tissue mitoses were absent (Fig. 1, Table 2). The stroma was edematous in both groups, but, whereas stromal mitoses were observed in normally cyclic cows, the mitoses were not seen in repeat breeder cows (Fig. 1, Table 2). In both groups, metrorrhagia was observed, while basal vacuolation and leukocyte infiltration were absent (Fig. 1).

Table 2. Significant morphological changes occurring in the endometrium

\begin{tabular}{|c|c|c|c|c|}
\hline $\begin{array}{l}\text { Day of } \\
\text { estrous } \\
\text { cycle }\end{array}$ & Contrast & Index & Mean (Range) & Significance \\
\hline 1 & $\begin{array}{l}\text { Normal cows } \\
\text { vs } \\
\text { Repeat breeder } \\
\text { cows }\end{array}$ & $\begin{array}{l}\text { Stromal mitoses } \\
\text { (no. of mitotic cells) }\end{array}$ & $0.9(0-2.0) / 0(0)$ & $P=0.018$ \\
\hline \multirow[t]{3}{*}{8} & $\begin{array}{l}\text { Normal cows } \\
\text { vs }\end{array}$ & $\begin{array}{l}\text { Secretion of glands } \\
\text { (scores) }\end{array}$ & $2.0(1.0-2.6) / 1.0(0.5-1.6)$ & $\mathrm{P}=0.050$ \\
\hline & $\begin{array}{l}\text { Repeat breeder } \\
\text { cows }\end{array}$ & $\begin{array}{l}\text { Pseudodecidual reaction } \\
\text { (scores) }\end{array}$ & $1.1(1.0-1.3) / 0.1(0-0.5)$ & $\mathrm{P}=0.011$ \\
\hline & & Metrorrhagia (scores) & $0(0) / 0.9(0-1.5)$ & $P=0.031$ \\
\hline
\end{tabular}




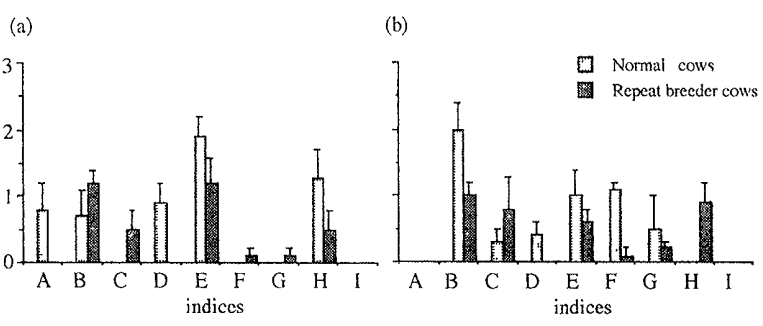

Fig. 1. Histological changes in normal cyclic heifers, in normal cyclic cows and in repeat breeder cows on Day 1 (a) and Day 8 (b). $\mathrm{A}=$ glandular mitoses, $\mathrm{B}=$ secretion of glands, $\mathrm{C}=$ supranuclear vacuolation, $\mathrm{D}=$ stromal mitoses, $\mathrm{E}=$ stromal edema, $\mathrm{F}=$ pseudodecidual reaction, $\mathrm{G}=$ leukocyte infiltration, $\mathrm{H}=$ metrorrhagia, $\mathrm{I}=$ basal vacuolation of the surface epithelial cells.

On Day 8, no significant difference was observed between the specimens obtained from left and right horns, hence, these results were combined. In all animals, the uterine glands contained voluminous secretions, and no mitoses (Fig. 1). There were no significant differences in the glandular scores between Day 8 and Day 1 in the repeat breeder cows. Stromal mitoses were absent in repeat breeder cows, and were few in normal cows. pseudodecidual reaction was prominent in the normally cyclic cows but not in the repeat breeder cows (Fig. 1, Table 2). Furthermore, metrorrhagia was observed in the repeat breeder cows only.

Plasma progesterone concentrations in the repeat breeder cows were less than $1.0 \mathrm{ng} / \mathrm{m} l$ on Days 0 and 1 , and increased to greater than $3.6 \mathrm{ng} / \mathrm{m} l$ on Day $8(0.5 \pm$ $0.1 \mathrm{ng} / \mathrm{m} l$ versus $4.7 \pm 1.1 \mathrm{ng} / \mathrm{m} l$, mean $\pm \mathrm{S} . \mathrm{D} ., \mathrm{P}<0.05)$, while the progesterone levels in the normally cyclic cows were $0.4 \pm 0.1 \mathrm{ng} / \mathrm{m} l$ on Days 0 and 1 and $5.2 \pm 0.9 \mathrm{ng} / \mathrm{m} l$ on Day 8. There were no significant differences in progesterone levels between the normally cyclic cows and the repeat breeder cows.

Bacteria were isolated from 3 uterine flushings on only Day 8: Staphylococcus epidermidis, Streptococcus sp., Escherichia coli. These results were in general characteristics of the normal flora in the healthy uterus as established by previous investigators [4].

\section{DISCUSSION}

In the present study, the diagram on heifers [15] enabled us to estimate the specimens from cows on Days 1 and 8 (Table 2), because there were no significant differences in endometrial morphology between nulliparous and multiparous animals. Thus, the specimens from repeat breeder cows were evaluated using these methods, and were estimated whether the endometrium properly developed during periimplantation.

The importance of utero-embryonic synchrony in embryo transfer has been reported previously in various species including cattle [16]. Compared to some species, embryos of cows and sheep lack flexibility in responding to uterine asynchrony [16]. We have shown in this study that asynchrony in endometrial development could cause cows to become repeat breeders. Imbalances of stromal versus glandular development were observed on Days 1 and 8 in the repeat breeder cows, but not in normal cows. First, in the repeat breeder cows on Day 1, uterine glands showed secretory shape, while the stroma showed only edema (Fig. 1). These specimens are assigned to Day 6 through Day 8 which corresponded to the stage indicated by the agreed indices [15]. In the normally cyclic cows, by contrast, each specimen is assigned to Day 1 through Day 2 , based on the histologic appearance of gland (Fig. 1). Second, in repeat breeder cows on Day 8, stromal changes were not observed, while the glands showed secretions (Fig. 1). Hence, the specimens are assigned to Day 13 through 19 , although the tissues from normal cows are assigned to Day 5 through Day 8. The findings of asynchrony between gland and stroma were similar to the results of a study in infertile women $[3,10]$, and suggest the importance of appropriate synchronous development of the endometrium.

It is not clear how endometrial asynchrony develops in repeat breeder cows. Corpus luteum dysfunction might induce stromal regression, because development of glandular and stromal cells is induced by increasing amounts of endogenous progesterone [5]. However, some authors reported a lack of difference in plasma progesterone between normal and repeat breeder cows $[2,20]$. Our results support these findings. In contrast, shortly after corpus luteum formation, cows with abnormally developing embryos have lower progesterone levels than those with normally developing embryos $[7,8,12,14]$. Another mechanism which may lead to endometrial asynchrony and embryo loss in repeat breeder cows is delayed formation of the corpus luteum leading to a sequence of improper hormonal changes. However, this does not appear to be a satisfactory explanation of the endometrial asynchrony because glands showed secretory shape in these cows on Day 1.

Furthermore, since progesterone concentrations were normal on Day 8, a local defect in endometrial response may be postulated. In the present study, a lack of difference was observed between the results obtained from the uterine horns ipsilateral to the ovary with the corpus luteum and those obtained from contralateral horns. It has been reported that tissues adjacent to the ovary bearing the corpus luteum contained greater quantities of progesterone than those on the contralateral side $[17,22]$. Note that since endometrial growth and development are induced by progesterone [17] and that in cattle, pregnancy rates are improved after transfer of embryos to the uterine horn ipsilateral to the ovary with corpus luteum [19]. In the cow and ewe the uteroovarian vein is closely adherent to the ovarian artery allowing countercurrent exchange to occur. Some investigators demonstrated that progesterone is concentrated via the countercurrent exchange between the uteroovarian vein and the ovarian artery in the ewe [21]. Thus, a local defect in the circulation of the blood might decrease uterine progester- 
one in the repeat breeder cows. Further studies should provide the relationships between changes in the endocrine milieu and endometrial response.

It has been shown that the women patients who demonstrated glandular stromal imbalances had low numbers of progesterone-binding sites in the endometrium [10]. Unfortunately Almeida et al. [1] demonstrated that concentrations of uterine endometrial receptors for progesterone on Day 6 were higher in repeat breeder cows than in normal cows. It is not known whether or not repeat breeder cows had fewer receptors in this study. However, it is suggested that insufficiency of the progesterone receptors could cause glandular-stromal imbalances in the repeat breeder cows. Furthermore, only one ratio of progesterone to estradiol supports development of normal secretory endometria [6]. The pattern of plasma estradiol and progesterone is a further complication that must be addressed.

In conclusion, this study shows that endometrial asynchrony might result in cows repeat breeding, and that uterine biopsy will aid the investigation of diagnostic methods in these cows.

ACKNOWLEDGEMENTS. We thank Dr. L. R. Abeydeera for his valuable comments in course of preparing this manuscript. This study was supported in part by a Grant-in-Aid for Scientific Research from the Ministry of Education, Science, and culture of Japan (No. 05806039).

\section{REFERENCES}

1. Almeida, A. P., Ayalon, N., and Bartoov, B. 1987. Progesterone receptors in the endometrium of normal and repeat breeder cows. Anim. Reprod. Sci. 14: 11-19.

2. Ayalon, N. 1981. Embryonic mortality in cattle. Zuchthygiene 16: 97-109.

3. Cumming, D. C., Honore, L. H., Scott, J. Z., and Williams, K. P. 1985. The late luteal phase in infertile women: comparison of simultaneous endometrial biopsy and progesterone levels. Fertil. Steril. 43: 715-719.

4. Dawson, F. L. M. 1959. The normal bovine uterus, physiology, histology and bacteriology. Vet. Rev. Annot. 5: 73-89.

5. Finn, C. A. and Martin, L. 1971. Endocrine control of the proliferation and secretion of uterine glands in the mouse. Acta Endocrinol. 155 (Suppl. 139) (abstr.)

6. Good, R. G. and Moyer, D. L. 1968. Estrogenprogesterone relationship in the development of secretory endometrium. Fertil. Steril. 19: 37-49.

7. Guise, M. B. and Gwazdauskas, F. C. 1987. profiles of uterine protein in flushings and progesterone in plasma of normal and repeat-breeding dairy cattle. J. Dairy Sci. 70: 2635-2641.

8. Gustafsson, H., Larsson, K., Kindahl, H., and Madej, A. 1986. Sequential endocrine changes and behaviour during oestrous and metoestrus in repeat breeder and virgin heifers. Anim. Reprod. Sci. 10: 261-273.

9. Hafez, E. S. E. 1987. pp. 410-411. Reproduction in Farm Animals. Lea \& Febiger, Philadelphia.

10. Keller, D. W., Wiest, W. G., Askin, F. B., Johnson, L. W., and Strickler, R. C. 1979. Pseudocorpus luteum insufficiency: a local defect of progesterone action on endometrial stroma. J. Clin. Endocrinol. Metab. 48: 127-132.

11. Makino, T. 1973. Radioimmunoassay of plasma sex steroids. Folia Endoc. Japonica 29: 629-646.

12. Maurer, R. R. and Echternkamp, S. E. 1982. Hormonal asynchrony and embryonic development. Theriogenology 17: 11-22.

13. National Research Council. 1978. Nutrient Requirements of Dairy Cattle. Natl. Acad. Sci. Washington, D. C.

14. Northey, D. L., Barnes, F. L., Eyestone, W. H., and First, N. L. 1985. Relationship of serum progesterone, luteinizing hormone and the incidence of pregnancy in bovine embryo transfer recipients. Theriogenology 23: 214 (abstr.)

15. Ohtani, S., Okuda, K., Nishimura, K., and Mohri, S. 1993. Histological changes in bovine endometrium during the estrous cycle. Theriogenology 39: 1033-1042.

16. Pope, W. F. 1988. Uterine asynchrony: a cause of embryonic loss. Biol. Reprod. 39: 999-1003.

17. Pope, W. F., Maurer, R. R., and Stormshak, F. 1982. Distribution of progesterone in the uterus, broad ligament, and uterine arteries of beef cows. Anat. Rec. 203: 245-250.

18. Shiotani, M., Takakura, K., Noda, Y., Fujiwara, H., Narimoto, K., Mori, T., and Kinoshita, M. 1991. Pituitaryovarian-endometrial axis in luteal phase defect. Jpn.J. Fertil. Steril. 36: 77-82.

19. Sreenan, J. M., Beehan, D., and Mulvehill, P. 1975. Egg transfer in the cow: factors affecting pregnancy and twinning rates following bilateral transfers. J. Reprod. Fertil. 44: $77-85$.

20. Tanabe, T. Y., Hawk, H. W., and Halser, J. F. 1985. Comparative fertility of normal and repeat-breeding cows as embryo recipients. Theriogenology 23: 687-696.

21. Walsh, S. W., Yutrzenka, G. J., and Davis, J. S. 1979. Local steroid concentrating mechanism in the reproductive vasculature of the ewe. Biol. Reprod. 20: 1167-1171.

22. Weems, C. W., Weems, Y. S., Lee, C. N., and Vincent, D. L. 1989. Progesterone in uterine and arterial tissue and in jugular and uterine venous plasma of sheep. Biol. Reprod. 40: 1-6.

23. Weitlauf, H. M. 1988. Biology of implantation. pp. 231-262. In: The Physiology of Reproduction (Knobil, E., Neill, J. et al. eds.), Raven Press, New York.

24. Wentz, A. C. 1980. Endometrial biopsy in the evaluation on infertility. Fertil. Steril. 33: 121-124. 